\title{
PRÁVNÍ ASPEKTY PRACOVNĚ PSYCHOLOGICKÉ DIAGNOSTIKY
}

\author{
MATĚj STŘíTESKÝ \\ Filosofická fakulta Masarykovy univerzity ${ }^{1}$, Liga lidských práv²
}

\begin{abstract}
Abstrakt: Předkládaný článek se zamýšlí nad tím, zda existuje právní úprava, která reguluje používání psychologické diagnostiky v pracovněprávních vztazích. Článek dochází k závěru, že právní úprava pracovně psychologické diagnostiky existuje, protože se jedná o formu zjišt'ování informací o zaměstnancích nebo uchazečů o zaměstnání. Článek řeší např. otázku, jaké testy může pracovní psycholog používat, zda musí poskytnout výsledky testů testovanému, či zda existují sankce za porušení vyvozených pravidel. Na základě analýzy právní úpravy autor vyvozuje pravidla, pro používání psychologické diagnostiky v pracovně právních vztazích. Své závěry se autor snaží ověřovat dotazy na správní orgány, které vykonávají dohled nad dodržováním relevantní právní úpravy.
\end{abstract}

Klíčová slova: pracovně-psychologická diagnostika, právo, osobní údaj, zákon

\section{Úvod}

Článek se zamýšlí nad pracovně psychologickou diagnostikou z pohledu práva. Psychologické testy představují nástroj k zjišt'ování informací o člověku, přičemž rozsah informací, které může o zaměstnanci či uchazeči o zaměstnání zaměstnavatel zjišt'ovat, je právně regulován. Informace získané pracovně psychologickým vyšetřením mohou mít povahu informací o duševním zdraví člověka, a jedná se o informace vysoce citlivé, je tak otázkou, kdo by je měl být oprávněn získávat a jak by s nimi mělo být nakládáno.

Článek vychází z diplomové práce autora, kterou obhájil na Právnické fakultě Masarykovy univerzity (Stříteský, 2016), jejíž plné znění je volně k dispozici v informačním systému Masarykovy univerzity. Stejně jako uvedená diplomová práce si článek klade dvě zásadní otázky:

- Existuje právní regulace dopadající na užívání psychologických testů v pracovněprávních vztazích?

- Jaké povinnosti případná právní úprava spojuje s užíváním psychologických testů v pracovněprávních vztazích a jaké jsou sankce za jejich porušení?

\footnotetext{
${ }^{1}$ Filosofická fakulta Masarykovy univerzity, Arna Nováka 1, 60200 Brno

${ }^{2}$ Liga lidských práv, Burešova 6, 60200 Brno.

Doručeno do redakce: 27. 8. 2017.
} 
Článek je navíc rozšířen o informace, které autor po dokončení diplomové práce získal od Úřadu pro ochranu osobních údajů.

\section{Právní regulace pracovně psychologické diagnostiky}

Obecná právní regulace používání psychologických testů v České republice neexistuje. Nacházíme regulaci testování $\mathrm{v}$ dílčích oblastech psychologické diagnostiky, např. dopravně psychologické vyšetření ${ }^{3}$, psychologické vyšetření budoucích státních zástupců a soudcư ${ }^{4}$, nebo vyšetření vojáků z povolání ${ }^{5}$. Pro drtivou většinu případů, kdy dochází psychologickému testování zaměstnanců nebo uchazečů o zaměstnání ale právní úprava chybí.

Ze zákonů tedy nezískáme výslovnou odpověd’ na otázku, jaké testy mohou být v pracovní psychologii používány a kdo je oprávněn je používat. Pokud ale přijmeme předpoklad, že psychologické testy slouží k zjišt'ování informací o testovaném, tak na ně dopadá právní úprava vymezující rámec informací, které smí zaměstnavatel o zaměstnanci či uchazeči o zaměstnání zjišt’ovat.

Za nejdůležitější pro řešenou problematiku považujeme tato ustanovení:

\section{§ 30 odst. 2 zákona č. 262/2006 Sb., zákoník práce}

„Zaměstnavatel smí vyžadovat v souvislosti s jednáním před vznikem pracovního poměru od fyzické osoby, která se u něj uchází o práci, nebo od jiných osob jen údaje, které bezprostředně souvisejí s uzavřením pracovní smlouvy."

\section{§ 316 odst. 4 zákona č. 262/2006 Sb., zákoník práce}

„Zaměstnavatel nesmí vyžadovat od zaměstnance informace, které bezprostředně nesouvisejí s výkonem práce a se základním pracovněprávním vztahem uvedeným v $\S 3$. Nesmí vyžadovat informace zejména o

a) těhotenství,

b) b) rodinných a majetkových poměrech,

c) c) sexuální orientaci,

d) původu,

e) členství v odborové organizaci,

f) členství v politických stranách nebo hnutích,

g) př́slušnosti $k$ církvi nebo náboženské společnosti,

h) trestněprávní bezúhonnosti;“"

to, s výjimkou písmen c), d), e), f) a g), neplatí, jestliže je pro to dán věcný důvod spočívající $v$ povaze práce, která má být vykonávána, a je-li tento požadavek přiměřený, nebo

\footnotetext{
${ }^{3}$ Viz § 87a zákona č. 361/2000 Sb., o provozu na pozemních komunikacích

${ }^{4}$ Viz $§ 2$ odst. 3 a 4 vyhlášky ministerstva spravedlnosti č. 303/2002 Sb.

5 Viz § 7 odst. 3 písm. l) vyhlášky ministerstva obrany č. 357/2016 Sb.
} 
$v$ př́padech, kdy to stanoví tento zákon nebo zvláštní právní předpis. Tyto informace nesmí zaměstnavatel získávat ani prostřednictvím třetích osob."

\section{§ 12 odst. 2 zákona č. 435/2004 Sb., o zaměstnanosti}

„Zaměstnavatel nesmí při výběru zaměstnanců vyžadovat informace týkající se národnosti, rasového nebo etnického pưvodu, politických postojů, členství v odborových organizacích, náboženství, filozofického přesvědčení, sexuální orientace, není-li jejich vyžadování $v$ souladu se zvláštním právním předpisem, dále informace, které odporují dobrým mravům, a osobní údaje, které neslouží k plnění povinností zaměstnavatele stanovených zvláštním právním předpisem. Na žádost uchazeče o zaměstnání je zaměstnavatel povinen prokázat potřebnost požadovaného osobního údaje. Hlediska pro výběr zaměstnanců musí zaručovat rovné příležitosti všem fyzickým osobám ucházejícím se o zaměstnání. Ustanovení $\$ 4$ platí i zde."

\section{§ 5 odst. 2 zákona č. 101/2000 Sb., o ochraně osobních údajů}

„Správce může zpracovávat osobní údaje pouze se souhlasem subjektu údajů...."

\section{§ 12 zákona č. 101/2000 Sb., o ochraně osobních údajů}

„Požádá-li subjekt údajů o informaci o zpracování svých osobních údajü, je mu správce povinen tuto informaci bez zbytečného odkladu předat."

\section{Právní povinnosti spojené s pracovně psychologickou diagnostikou}

V závěru zmiňované diplomové práce (Stříteský, 2016) vyvodil autor na základě výše zmiňovaných právních předpisů dopadajících na pracovně psychologické vyšetření čtyři pravidla, o kterých se domnívá, že by měla být při používání psychologických testů v pracovněprávních vztazích dodržována. Zmíněná pravidla uvádíme níže včetně jejich odůvodnění.

1. Testem zjišt'ovaná informace (vlastnost či dovednost) má bezprostředně souviset s pracovní pozicí zaměstnance, nebo s pracovní pozicí, na kterou je vybíráno.

Toto pravidlo vyplývá z uvedeného $§ 30$ a § 316 zákoníku práce. Klíčovým pojmem je zde bezprostřední souvislost, který odborná literatura (Morávek, 2013, s. 377) definuje následovně: „Bezprostřední souvislostí se rozumí všechny údaje, které jsou nutné ke svobodnému a vážnému rozhodnutí zaměstnavatele o tom, že s konkrétním zaměstnancem uzavře pracovní poměr, tj. všechny údaje nutné k tomu, aby byla oferta zaměstnání zaměstnavatele ve vztahu $k$ uchazeči o zaměstnání právním úkonem se všemi náležitostmi, zejména ve smyslu svobody vůle, resp. absence omylu." 
Z uvedeného vyplývá, že rozsah informací, které zaměstnavatel smí od zaměstnance vyžadovat, není omezen např. pouze na informace osvědčující skutečnosti požadované pro výkon práce právními předpisy. Vždy ale musí být obhájitelné, proč zjišt’ované informace mají nějak souviset s obsazovanou pozicí. Zjednodušeně pokud se na něco ptáme, měli bychom vědět, proč to děláme.

Ne všechny vlastnosti jsou rozhodné pro všechna povolání. U každého testu je potřeba zkoumat, zda jím měřená vlastnost bezprostředně souvisí s uzavřením konkrétní pracovní smlouvy s testovanou osobou, nebo s konkrétním pracovním poměrem, v němž se nachází testovaný zaměstnanec. Jako problematické se tak může jevit používání stejných testových baterií pro výběr na různé pracovní pozice.

Z uvedeného § 12 zákona o zaměstnanosti navíc vyplývá, že zaměstnavatel je testované osobě povinen prokázat, že takovou informaci od uchazeče skutečně potřebuje. Např. prokázání toho, že pro rozhodnutí o přijetí uchazeče jsou důležité preference určitých barev, vnímáme jako komplikované.

V případě, že je uchazeč vybírán na pozici, která je vstupní pozicí, z níž se přepokládá po zapracování přeřazení na pozice vyžadující vyšší míru odbornosti, v takovém případě je dle mého názoru obhajitelné, zjišt’ovat i informace související s touto navazující pracovní pozicí.

Dalším důležitým pojmem je zde pojem "vyžadovat informace“, jsem přesvědčen, že tímto pojmem je potřeba rozumět veškerou aktivitu zaměstnavatele, či jím zprostředkovaných osob, která může vést k získání konkrétní informace. Informaci tak vyžadujeme, i pokud tázanému umožníme nezodpovědět položenou otázku.

\section{Testem nemají být zjišt'ovány informace, které zákon výslovně zakazuje zjišt'ovat a to např. informace o sexuální orientaci testovaného, či jeho náboženském vyznání.}

To, že nesmíme činit, co nám zákon zakazuje je zřejmé, přesto se můžeme setkat s tím, že v osobnostních dotaznících, které nejsou primárně určeny pro pracovní psychologii, jsou obsaženy otázky, které směřují na oblasti, jež výše uvedený § 316 zákoníku práce zakazuje zjišt'ovat. Může se jednat např. o otázky obsažené v MMPI II (Pope, Butcher, Seelen, 2006, s. 234 - 235):

- „Často jsem si přál být dívkou či ženou. (Nebo pokud jste žena) Nikdy mě nemrzelo, že jsem ženou.

- Věřím v posmrtný život" 6

\footnotetext{
${ }^{6}$ Používáme zde položky námi přeložené z anglického originálu, česká verze testu nám nebyla dostupná, nicméně správnost našeho překladu jsme konzultovali s kolegy z řad studentů psychologie, kteři se s testem setkali v průběhu praxí: „I have often wished I were a girl. (Or if you are a girl) I have never been sorry that I am a girl" "I believe in a life hereafter."
} 
Námitka, že pokládáním uvedených otázek nám primárně nejde např. o zjištění sexuální orientace nebo víry testovaného, ale že pomocí těchto otázek usuzujeme na povahové rysy, které se právě v odpovědi na tyto otázky projeví, je lichá. Smyslem uvedených zákonných ustanovení je chránit soukromí zaměstnanců a zásah do soukromí, který kladení takovýchto otázek představuje, je stejný at’ už je klademe za jakýmkoliv účelem. Je proto vhodné zkontrolovat dotazníkové baterie a zamyslet se, zda některé jejich otázky nesměřují na informace zákonem zakázané zjišt'ovat od zaměstnanců či uchazečů o zaměstnání.

Argument, že ani jedna $\mathrm{z}$ pokládaných otázek přímo nesměřuje k zjištění zákonem zakázaných témat, nepovažuji za správný. Pokud bychom $§ 316$ zákoníku vnímali pouze tak, že se nesmíme ptát pouze přímo např. na to, zda je žena těhotná, ale naopak na otázku „Chtěla byste děti v budoucnu“ se ptát můžeme, protože ne každá žena, která děti chce, v budoucnu otěhotní, tak bychom naprosto negovali zákonnou ochranu. Nemohli bychom se sice ptát např. „Jste žid nebo muslim?“, „Jste homosexuál?“ ale naopak bychom se mohli ptát, „Chutná Vám vepřové a pracujete v sobotu?“ nebo „Přitahují Vás muži?“.

Pokud by personalisté chtěli dosáhnout možnosti klást otázky, které zákon zakazuje zjišt'ovat zaměstnavatelům, muselo by toto jejich specifické postavení být zakotvené v právním řádu a muselo by být pravděpodobně "zaplaceno" zákonně uloženou povinností mlčenlivosti.

3. Test, pokud není prováděn poskytovatelem pracovnělékařských služeb (potažmo klinickým psychologem) v rámci pracovnělékařského vyšetření, nemá poskytovat informace ozdravotním stavu testovaného např. srovnáním jím dosažených výsledků s výsledky klinické populace.

Zájem zaměstnavatele na zaměstnávání osob zdravotně způsobilých k výkonu práce je zřejmý a povinnost nepřipustit, aby zaměstnanec vykonával takové práce, které neodpovídají jeho zdravotní způsobilosti, ukládá zaměstnavateli § 103 odst. 1 písm. a) zákona č. 262/2006 Sb., zákoníku práce. Na druhé straně je zájem zaměstnance na ochraně jeho soukromí zaručovaný čl. 7 odst. 1 a čl. 10 odst. 3 zákona č. 2/1993 Sb., Listiny základních práv a svobod, přičemž dle našeho názoru existuje jen málo soukromějších informací o člověku než informace o zdravotním stavu. Tento názor můžeme podepřít argumentací Evropského soudu pro Lidská práva, který ve věci Z. proti Finsku uvedl, že „ochrana osobních dat, o to více lékařských dat, má pro požívání práva na respektování soukromého života základní význam. (Cit dle Kmec, 2012, s. 917)

Spor mezi dvěma protichůdnými zájmy je řešen institutem pracovního lékařství, díky kterému zaměstnavatel získá informace, zda je zaměstnanec či uchazeč o zaměstnání zdravotně způsobilý k výkonu práce, zatímco podrobné informace o zdravotním stavu zaměstnance zůstávají v režimu zdravotnické dokumentace dle zákona č. 372/2011 Sb., o zdravotních službách, a je tak lépe zajištěna jejich ochrana.

Posudek, který je výsledkem pracovně-lékařské prohlídky, může pouze konstatovat že: 
„zaměstnanec je schopen vykonávat navrhovanou práci nebo zamëstnanec je schopen vykonávat uvedenou práci jen za určitých podmínek, nebo zaměstnanec je neschopen vykonávat navrhovanou práci." (Galvas, 2012, s. 483),

poskytnutí dalších informací by bylo porušením lékařského tajemství.

Mnoho testových metod vychází z toho, že výsledek posuzované osoby srovnává s výsledkem klinické populace a tím se zjišt'ovaná informace stává informací o zdravotním stavu. Takovéto testy nemají být používány v pracovní psychologii, protože náleží do rukou zdravotníků. Neoprávněným zjišt'ováním informací o zdravotním stavu člověka dochází k zásahu do jeho soukromí.

Pokud test umožňuje člověka nesrovnávat s klinickou populací a pokud na základě jeho výsledků personalista nespekuluju o zdravotním stavu, tak není zjišt’ována informace o zdravotním stavu test a může být používán.

4. Test má být validní, protože pokud není jisté, co test zjišt'uje, nelze ani tvrdit, že testem zjišt'ovaná informace souvisí s pracovní pozicí, nebo s pozicí na kterou je vybíráno. A účel testování má být zaměstnanci či uchazeči o zaměstnání před testování sdělen.

Pokud panují pochybnosti o tom, co používaná metoda zjišt'uje, můžeme jen stěží dodržet zákonem uloženou povinnost zjišt’ovat pouze informace bezprostředně související s obsazovanou pozicí, proto by neměly být používány metody, o jejichž validitě existují u odborné veřejnosti pochyby. Uvedeným není myšleno, že by mohly být používány pouze metody, jejichž validita je neochvějně přijímána napříč celým psychologickým oborem, ale že by měly existovat argumenty pro validitu testu, jejichž pravdivost je možné přezkoumat. Psychologické testování by prostě nemělo být dojmologickým věštěním z křrištálové koule.

Z uvedeného $§ 5$ zákona o ochraně osobních údajů vyplývá, že informace o testovaném mohou být zjišt’ovány pouze na základě jeho souhlasu. Přičemž k vlastnostem tohoto souhlasu odborná literatura (Novák, 2014, s. 126) uvádí. „Aby souhlas se zpracováním osobních údajů byl platný a zpracování probíhalo v souladu s ZOOÚ je třeba aby [...] ten, kdo souhlas poskytuje, byl předem informován, za jakým účelem, kým na jak dlouho a konkrétně jaké jeho osobní údaje budou zpracovávány (obecná formulace typu souhlasím se zpracováním svých osobních údajủ dle zákona o ochraně osobních údajü, se kterou se Úřad ve své praxi setkává, je tedy zásadně nevyhovující)."V úvahu tak nepřichází využívání testů, při jejichž administraci je zatajováno nebo nepravdivě uváděno, co testy skutečně zjištujuí.

\section{Sankce za porušení pravidel}

Důležitou otázku představuje i to, zda za porušení uvedených pravidel mohu být uloženy sankce. Státní úřad inspekce práce může poměrně nově uložit dle $\S 11 \mathrm{a}$ zákona č. 251/2005 o inspekci práce pokutu za zjišt’ování informací, které zakazuje zjištovat $\S 316$ odst. 4 zákoníku práce. Výše pokuty může být až 100.000 Kč. Došlo tak ke změně situace oproti situaci v době dokončování diplomové práce (Stříteský, 2016), kdy mohla 
být ukládána "pouze" doporučení k nápravě bez finanční sankce. Správní řízení o řešení přestupku na úseku ochrany soukromí a osobnostních práv zaměstnanců, může do budoucna poskytnout argumentaci o pravdivosti předkládaných závěrů.

Na druhou stranu se domníváme, že porušení uvedených pravidel v řadě případi̊ zakládá sankční pravomoc Úřadu pro ochranu osobních údajů, který může ukládat nemalé pokuty. Nicméně v zahraničí již proběhly soudní spory, v nichž se zaměstnanec bránil vůči povinnosti absolvovat psychologické vyšetření, viz Rozsudek Kalifornského odvolacího soudu ve věci Soroka v. Dayton-Hudson.

\section{Další související otázky}

V závěru zmiňované diplomové práce (Stříteský, 2016) byly identifikovány následující otázky, které s problematikou souvisí.

Kdo může psychologické testy k psychologické diagnostice používat?

Pro osoby používající psychologické testy v souvislosti s pracovněprávními vztahy není legislativou stanoven žádný požadavek na odbornou způsobilost. Omezení pro to, aby určité testy používaly pouze osoby ktomu vzdělané, je aktuálně vynutitelné jen prostřednictvím těch, kteří testy distribuují. Do kupní smlouvy lze vložit podmínku, že test může být používán pouze osobou s určitou kvalifikací a porušení této povinnosti trestat smluvní pokutou a stejně tak lze považovat náhradu škody po tom, kdo test získá z jiného zdroje než od oprávněného distributora.

Další možnost ochrany poskytuje právo duševního vlastnictví, protože každý test lze vnímat jako autorské dílo a jeho použití bez souhlasu autora (např. v podobě udělené licence) je možné sankcionovat. Oběma postřehům je však společné, že aktivita na vynucování správného používání testů, leží na jejich distributorech.

Má testovaný právo nahlížet do výsledků testů?

Odpověd' na tuto otázku vyplývá opět z výše uvedeného § 12 zákona na ochranu osobních údajů, z uvedeného ustanovení vyplývá, že pokud testovaný požádá o zpř́stupnění výsledků testu, měl by mu tento výsledek být zpřístupněn. Jak má takové zpř́istupnění informací vypadat jsme zjišt’ovali od Úřadu na ochranu osobních údajů, odpověd' uvádíme níže.

Dopadají vyvozená pravidla pro používání testů kromě zaměstnavatele i na př́padnou personální agenturu jím najatou k testování zaměstnance či uchazeče o zaměstnání?

Odpověd' na otázku dle pohledu autora obsahuje dříve uvedený § 316 zákoníku práce, který stanoví, že zakázané informace nesmí zaměstnavatel získávat ani prostřednictvím třetích osob. Stejně tak autor nevidí rozdíl v zásahu do soukromí testovaného mezí situacemi, kdy ho testuje přímo zaměstnavatel, nebo zaměstnavatelem najatá personální agentura. Nicméně názor autora se neshoduje s názorem Úřadu inspekce práce, který je obsažen v př́loze citované diplomové práce (Autor, 2016). 


\section{Informace od Úřadu pro ochranu osobních údajů týkající se tématu}

Za účelem zjištění, jaké informace má testující testovanému poskytnout ohledně jeho výsledků se autor obrátil na Úřad na ochranu osobních údajů, k dotazu na to, jaké informace mají být testovanému subjektu poskytnuty, přiložil autor modelovou zprávu z výsledku psychologického vyšetření smyšleným testem OSEA. Na uvedený dotaz Úřad na ochranu osobních údajů odpověděl následovně. $Z$ uvedené odpovědi je důležité zejména následující:

„K tomu, aby bylo postupováno $v$ souladu se zásadami uvedenými v zákoně o ochraně osobních údaju a aby správce osobních údajů dodržel povinnosti, které mu tento zákon stanoví, Vám doporučuji postupovat tak, aby se subjekt údajů mohl otevřeně seznámit se všemi informacemi vztahujícími se $k$ psychologickému testování jednak $v$ obecné rovině (napríklad Vámi uváděný popis použitého dotazníku OSEA) a jednak v rovině, ve které se dá hovořit o informacích, které se vztahují pouze $k$ testované osobě jako $k$ subjektu údajü (kvantitativní výsledek testovaného subjektu a doporučení pro další práci s testovaným subjektem, jak uvádíte)."

Podle informací od Úřadu pro ochranu osobních údajů, tak má testovaný zaměstnanec či uchazeč o zaměstnání nárok na to, aby mu byly sděleny jeho výsledky v testu stejně srozumitelným zpo̊sobem jako byly poskytnuty zadavateli.

\section{Závěr}

Pro bližší informace čtenáře odkazujeme na zmiňovanou diplomovou práci. Uznáváme, že uvedená pravidla mohou být pro praktikující pracovní psychology pobuřující, v žádném případě netvrdíme, že právní názor autora je jediným možným. V případě, že čtenář má o závěrech autora pochybnosti, doporučujeme se s otázkami obracet na Úřad pro ochranu osobních údajů a Státní úřad inspekce práce, jejichž výklad práva může poskytnout lepší vodítko pro praxi. Hlavní myšlenkou práce je, že právo na pracovně psychologickou diagnostiku dopadá. Kladným vyzněním práce je, že úřady na položené otázky reagují a je zde tak prostor pro postupné vyjasnění nejasných otázek jiným způsobem než prostřednictvím soudních sporů.

\section{Zdroje}

\section{Publikace}

Galvas, M. (2012), Pracovní právo. 1. vyd. Brno: Masarykova univerzita, 2012, s. 88. Edice učebnic Právnické fakulty Masarykovy univerzity v Brně

Kmec, J. (2012). Evropská úmluva o lidských právech (komentář), 1. vyd., Praha, C. H. Beck.

Morávek, J. (2013) Ochrana osobních údajů v pracovněprávních vztazích. Vyd. 1. Praha: Wolters Kluwer. 
Novák, D. (2014) Zákon o ochraně osobních údajů a předpisy související: komentář. 1. vyd. Praha: Wolters Kluwer

Pope, K; Butcher, J and Sellen, J. (2006) The MMPI, MMPI-2: a practical guide for expert witnesses and attorneys. 3. aktualiz. vyd. Washington, DC: American Psychological Association.

Stříteský, M. (2016). Užívání psychologických testů v pracovněprávních vztazích. Brno. Diplomová práce.

\section{Právní předpisy rozsudky}

Zákon č. 372/2011 Sb., o zdravotních službách

Zákon č. 262/2006 Sb., zákoník práce

Zákon č. 435/2004 Sb., o zaměstnanosti

Zákon č. 361/2000 Sb., o provozu na pozemních komunikacích

Zákon č. 101/2000 Sb., o ochraně osobních údajů

Vyhláška ministerstva spravedlnosti č. 303/2002 Sb.

Vyhláška ministerstva obrany č. 357/2016 Sb

Rozsudek Kalifornského odvolacího soudu ve věci Soroka v. Dayton-Hudson ze dne 25. ř́jna 1991. Dostupný z: http://www.danpinello.com/Soroka.htm

Rozsudek Evropského soudu pro lidská práva ve věci Z. proti Finsku

\section{Matěj Stř́iteský (2018): Legal aspects of psychological testing in labour relationships}

The paper considers whether the Czech law includes any legal regulation of psychological testing in labour relations. The author argues that psychological testing in labour relations is indeed regulated by the law because psychological testing represents a type of obtaining information about an employee or a future employee. The paper proposes arguments why some tests should not be used for psychological testing in labour relations, why test takers have the right to access the results of testing. The paper also considers if there are any penalizations for not following the regulations. Based on the analysis of legal regulation the author proposes several rules for the use of psychological testing in labour relations. For the validation of his findings the author contacted legal authorities that enforce labour law.

Key words: psychological testing in labour relations, law, personal data, labour law 